\title{
当院に打ける大腿骨人工骨頭置換術の検討
}

\author{
山口赤十字病院整形外科 \\ 北田懐仁・福 岡善平 \\ 山本緑・塩田悦仁

\section{Postoperative Results of the Prosthetic Replacement of the Head of the Femur} \\ by \\ K. Kitada, Y. Fukuoka, M. Yamamoto \\ and E. Shiota \\ Orthopedic Surgery, Yamaguchi Red Cross Hospital

\begin{abstract}
The late results of the prosthetic replacements of femoral head in Yamaguchi Red Cross Hospital during the period from January 1969 to December 1978 (10 years) are reported.

During this period, 15 ? cases of the fractures of the femoral neck and 29 cases of the femoral capital necrosis were treated.

Among these cases, 86 cases were treated by osteosynthesis and 57 cases were treated by prosthetic replacement. Fifty-four of the latter are followed up in this paper.
\end{abstract}

大腿骨頸部骨折特に内側骨折は難治であり，一次的 に骨瘉合がおこっても壊死を続発するものああり，い ろいろな骨折の分類や血管学的研究によるもなお予後 の判定が困難とされている. また人工骨頭置換術後に も疼痛や migration の問題など解決されないととも 多い.

われわれは昭和 44 年より人工骨頭置換術を始め 50 例に達し，その予後調查を行なったので報告する.

当院において昭和 44 年より昭和 53 年までに入院治 療を行なった大腿骨頸部骨折は 195 例, 骨頭壊死は 29 例である. その内, 骨接合術を受けたものは 86 例, 人工骨頭置換術を受けたものは 57 例である.

人工骨頭置換術症例で資料の揃っているものは 54 例であり, 男 7 例, 女 47 例である. 手術時年令は 58 才から 88 才までで平均 71.9 才, 50 才代 3,60 才代 17,70 才代 27,80 才代 7 例である.

症例の内わけは内側骨折 49 例, 外側骨折 2 例, 特 発性骨頭壊死亡思われたものが 3 例である. 内側骨折 では受傷後 1 月以内の新鮮例 28 , 陳旧例が 21 例であ る. 骨接合術後のものが 5 例あり, うち 1 例は外側骨
折治癒後の骨頭壊死で, 他の 4 例は内側骨折術後の壊 死または仮関節である. 外側骨折の他の 1 例は高令の 外人で転子間の新鮮骨折であったが，早急に帰国を希 望したためこの手術を施行した.

\section{手術および後療法}

全例 Southern approach で Austin-Moore の 人工骨頭を使用，患肢に弛緩性麻疸があった 1 例を除 き骨セメントを使用せず，骨移植も行なっていない，

術後 3 週より杖歩行を開始する.

骨頭の摘出には大腿骨骨幹部をもって脱臼せしめえ ない場合は，神中の股関節成形用鳌を関節裂隙に入 れ，乙れを回転して残った関節包や円勒帯を切り，そ のままこれを挺子として脱臼させて臼の軟骨を損傷す ることなく容易に摘出せしめている.

摘出骨頭は消毒液用コップ内に入れ，その入り具合 を人工骨頭と比較する．規格により同じ大きさを得ら れない場合は，乙れになるべく近く小のものを使用し ている. 
表 1

\begin{tabular}{|c|c|c|c|c|c|c|c|c|c|c|c|c|}
\hline No. & 性 & $\begin{array}{l}\text { 手 } \\
\text { 術 } \\
\text { 時 } \\
\text { 年 } \\
\text { 令 } \\
\text { 热 }\end{array}$ & $\begin{array}{l}\text { 経 } \\
\text { 過 } \\
\text { 観 } \\
\text { 察 } \\
\text { 期 } \\
\text { 間 } \\
\text { 年 } \\
\text { 㲵 }\end{array}$ & 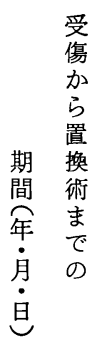 & $\begin{array}{l}\text { 日 } \\
\text { 整 } \\
\text { 会 } \\
\text { 判 } \\
\text { 定 } \\
\text { 基 } \\
\text { 準 } \\
\text { 点 } \\
\text { 数 }\end{array}$ & 部 & $\begin{array}{l}\stackrel{0}{\mathbb{D}} \\
\text { B } \\
\text { 周 } \\
\text { 囲 } \\
\text { の } \\
\text { 透 } \\
\text { 明 } \\
\text { 層 }\end{array}$ & $\begin{array}{l}\text { 所 } \\
\text { 性 }\end{array}$ & $\begin{array}{l}\text { 大 } \\
\text { 腿 } \\
\text { 骨 } \\
\text { 皮 } \\
\text { 質 } \\
\text { の } \\
\text { 肥 } \\
\text { 懕 } \\
\text { 硬 } \\
\text { 化 }\end{array}$ & $\begin{array}{l}\underset{P}{0} \\
\mathbb{B} \\
\text { 先 } \\
\text { 端 } \\
\text { の } \\
\text { 硬 } \\
\text { 化 }\end{array}$ & 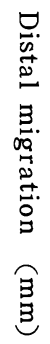 & 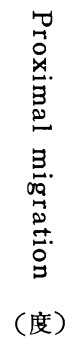 \\
\hline 1 & 오 & 60 & 6.0 & 2. 3. 0 & 72 & + & - & + & - & + & 4 & $\pi$ \\
\hline 2 & 우 & 58 & 5.8 & 0.2 .0 & 97 & - & - & - & - & 不 明 & 6 & 0 \\
\hline 3 & 우 & 61 & 5.6 & 0.0 .15 & 69 & + & - & - & - & - & 7 & II \\
\hline 4 & $\hat{0}$ & 59 & 4.7 & 数 年 & 59 & H & + & - & - & + & 8 & I \\
\hline 5 & 우 & 78 & 4.7 & 0.0 .9 & 66 & - & - & - & - & + & 5 & I \\
\hline 6 & $\begin{array}{l}+ \\
+ \\
+\end{array}$ & 72 & 4.5 & 0.0 .15 & 87 & - & - & - & - & + & 5 & I \\
\hline 7 & 우 & 72 & 4.1 & 1.6. 0 & 72 & + & - & - & - & + & 5 & II \\
\hline 8 & 우 & 81 & 3. 3 & 0.0 .23 & 42 & \# & - & - & - & + & 9 & II \\
\hline 9 & 우 & 79 & 2. 8 & 0.0 .5 & 64 & - & + & - & + & + & 14 & I \\
\hline 10 & $\hat{\delta}$ & 74 & 2.7 & 0.0 .20 & 17 & - & - & - & - & - & 7 & I \\
\hline 11 & 우 & 74 & 2.6 & 0.0 .10 & 68 & + & + & - & - & + & 8 & I \\
\hline 12 & o & 74 & 2. 2 & 0.1 .4 & 66 & - & - & - & - & + & 8 & I \\
\hline 13 & 오 & 72 & 1.5 & 0.3 .0 & 78 & - & - & - & + & + & 5 & $\bar{I}$ \\
\hline 14 & 우 & 71 & 1.4 & 0.3 .0 & 89 & - & - & - & - & - & 7 & I \\
\hline 15 & 委 & 70 & 1.3 & 0.5 .20 & 71 & + & - & + & + & + & 6 & II \\
\hline 16 & 우 & 71 & 1.1 & 0.0 .25 & 72 & - & - & - & - & + & 7 & 0 \\
\hline 17 & 우 & 75 & 0.11 & 0.3 .15 & 64 & + & - & - & - & + & 4 & I \\
\hline 18 & $\hat{\delta}$ & 72 & 0.11 & 1.0 .0 & 73 & + & - & - & - & 不 明 & 8 & 0 \\
\hline 19 & 우 & 73 & 0.10 & 1.3. 0 & 58 & + & - & + & - & + & 7 & 0 \\
\hline
\end{tabular}

\section{調查対象および方法}

54 通のアンケート調査中回答が得られたもの 36 通, その内死亡 9 名. 今回直接検診しえた 19 名を日整会 判定基準とレ線所見より評価した.

その症例は表に示すでとく男 3 名女 16 名で，平均 年令は 70.8 才である.

経過観察期間は 10 月から 1 年まで 3 例， 1 年から 5 年まで 13 例, 5 年以上 3 例である.

成績は置換術後の判定には問題はあるが，日整会変 股症判定基準によった.

レ線による検索法としては図のでとく，

a) proximal migration 術後および調查時の単 純レ線写真より，臼関節軟骨と考えられる距離 a が不 変で軟骨が温存されているものを 0 度, 半分以上残存 するものを I 度, 半分以下になったものをII 度, さら に軟骨下骨質までに達するあのを正度とする.

b ) distal migration 同様化人工骨頭の中心 $\mathrm{c}$ お よび小転子の頂点 $\mathrm{t}$ より大腿骨軸に下した交点 A B 間 の距離を比較し, 差がないものを 0 度, $5 \mathrm{~mm}$ 以内の あのを I 度, 6〜 10 $\mathrm{mm}$ を II 度, $11 \mathrm{~mm}$ 以上を III 度
Proximal migration a Distal migration $A B$

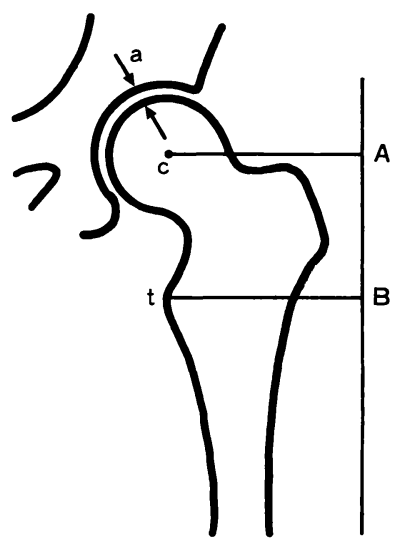

とする.

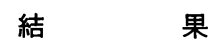

日整会判定基準で優 1 例, 良 8 例, 可 8 例, 不可 2 例であり, 平均 67.6 点. 不可の 2 例は共に脳軟化症 
の合併例である.

受傷から人工骨頭置換術までの期間について るる

と, 新鮮例 8 例のうち, 良 2 , 可 4 , 不可 2 例であ り, 陳旧例は 11 例のうち優 1 , 良 6 , 可 4 例であり, 陳旧例の成績が特に悪いとはいえない，

手術時年令でもこの症例の年令の範囲内では成績に 差をみない.

また術後経過についても 6 年以内という期間のため か, 経年的な低下の傾向はみられない.

\section{レ線検索について}

1）明かに loosening と思われたあのはないが, 人工骨頭の stem 亿接する部位に透明像をみるもの が 3 例あったが，大腿部の疼痛と必ずしも一致しなか った. また大腿骨皮質の肥厚と硬化が 3 例に認めら れ, stem 尖端部の硬化が 14 例に認められたが，い ずれあいたみや成績と明かな関係はなさそうである.

2）異所性化骨, 日蓋側に 2 例, 頸部に 1 例認めら れ，すべて大腿部痛があったが，関節可動域の減小は 明かでない。

3) proximal migration 0 度 4 , I 度 10, II 度 5 ，度 0. 乙れは術後経過年数や成績に影響してい ない.

人工骨頭径と 健側の 骨頭陰影の大きさを比較した が, 健側より小さいものはなかった.

4) distal migration I 度 6 , II 度 12 , III 度 1 例 あり, 平均 $6.8 \mathrm{~mm}$. 林度の 1 例 $14 \mathrm{~mm}$ は骨頭の打 込み不足と思われるものであるが，成績に関係はなさ そうである。

\section{合併症}

1）術中頸部の骨折 1 例，乙の手術の第 1 例目で手 術手技未熟によるあの.

2) 脱臼 2 例， 1 例は新鮮な脱臼骨折で臼蓋，骨頭 および頸部に骨折があり, 置換手術直後に後方脱臼を 起こしたが，直ちに観血的整復術を行ない，回旋中間 位に牽引し経過良好. 1例は骨頭壊死の急速に進行し た例であり, 術後 3 月で曰蓋後上方破壊を起こし亜脱 曰したもので, 全人工関節置換術を行なった. 後日他 の小関節にも症状が表れ R Aであるととが判明した.

3）術後感染例はなかった.

\section{むす び}

われわれは昭和 45 年より主に大腿骨内側骨折に人 工骨頭置換術を行なって来たが，その適応については 特に定めていない，骨接合を行なったものあ，非観血 的に取扱ったものあある. しかし，長期臨床に堪えな いと考えられた場合や高度の骨頭壊死例では臼蓋に変 化のないものを選びての手術を行なった.

骨接合術は理想的であるが, 反面長期安静が必要で あり，また一応治癒したと思われる症例にも骨頭壊死 が起てるのをみると, あえて人工骨頭置換術の適応も あるかと考える.

あちろん骨粗鬆症の強いもの，放射線障害あるいは 変股症などで，骨盤側にも変化があるものや，それが 予測される場合は適応はない.

年令, 一般状態, 精神状態, 社会的条件などを考虑 に入れて，個々の症例に応じて適応を選べば，ある程 度の治療成績を得られる手術であると考える.

\section{文献}

1) 明石武彦ほ加: 単純人工骨頭置換術の術後成樍 について. 中部整災, 18. 320-323, 1973.

2）天児民和，杉岡洋一：大腿骨頸部骨折の治療. 整形外科, 20. 541-546, 1969.

3) Garden R. S. : Stability and union in subcapital fractures of the femur J. B. J. S. 46. B 630-647, 1964.

4）伊丹康人：人工骨頭（股関節），日整会誌，43. 1087-1097, 1969.

5）伊藤鉄夫ほか: 大腿骨頸部内側骨折の形式と骨 頭の変化. 整形外科, 23.1-7, 1972.

6）柏木大治ほ加：AUSTIN-MOORE 型人工骨頭 置換術の適応とその治療成樍. 災害医学, 15 . 653-662, 1972.

7）柏木大治ほ加：人工骨頭置換術後の追跡調查. 臨整外, 8. 368-378, 1973.

8）増田武志ほか：大腿骨頭無腐性壊死飞おける人 工骨頭置換術の成樍. 臨整外, 13, 31-37, 1978.

9) Nieminen, S. \& Satokari, K.: Classification of medial fractures of the femoral neck, Acta Orthop. Scand., 46: 775-781, 1975.

10) Sarmiento, A.: Austin-Moore prosthesis in the arthritic hip. Clin. Orthop., 82. 14, 1972.

11）紫藤徹郎ほか：大腿骨頸部内側骨折における大 腿骨頭の血行. 53回中部日本整災学会.

12）鈴木一太：大腿骨頸部骨折における観血的治療 
の検討. 日整会誌，51.993-994，1977.

13）鈴木茂夫ほか：人工骨頭置換術後の成績. 中部 整災, 22. 26 33, 1979.

14）高樹定雄ほ加：大腿骨頸部骨折に対する人工頭 置換術の小経験. 臨整外, 6. 534-538, 1971.

15)田島 明ほか：大腿骨頸部骨折に対する人工骨 頭置換術の経験. 中部整災, 15. 581-583, 1972.

16）丹菊臣生ほ加：人工骨頭置換術後合併症. 中部 整災, 19. 256-258, 1979.

17）山本 真：大腿骨頸部内側骨折に対する新しい 骨接合術の試み. 整形外科, 29. 825-832, 1978.

18）山下守昭ほか：大腿骨内側骨折後の骨頭変化. 日整会誌，51.989-990，1977.

\section{質 問 福岡整形外科病院 徳永 純一} 内側骨折例で, 人工骨頭置換例之骨接合例との比率 は如何?

人工骨頭置換の indication は如何?

Non-union 例では, 当初より人工関節置換が考え られる場合があるのではないか？

\section{追加・質問 山口県立中央病院引引削大四郎}

(1) われわれも過去 2 回人工骨頭置換術症例の治療 成績を発表したが，正常に近いものは $60 \%$ にすぎな かった。

(2) 昨年のフランス整形災害外科学会で単純人工骨 頭置換術のシンポジゥムが行なわれたので，その概要 を紹介する．

a ） 830 例中，僅か臨床的には $56 \%$ X線学的には $54 \%$ み正常に近い成績であった.

b ) 不良例の原因は「寛骨臼炎」(Cotyloidele)を 呈していた.

c ）寛骨曰鼠な関節軟骨と軟骨下骨組織により股関節 の状態に応じ変形するが，金属製の人工骨頭には弾性 変形がないのでここに寛骨臼炎の発生する原因があ る.

d) Thompson 型で cementing したものが最も 成績がよく， austin-Moore 型で non-cementing のあのが最も成績が悪かった.

e ）人工骨頭径は骨性寛骨臼より小さいものの方が 合併症が少ない. 